\title{
Bioconversion of Waste Foolscap and Newspaper to Fermentable Sugar
}

\author{
Modupe E. Ojewumi ${ }^{*}$, Oluwatobi E. Kolawole', Daniel T. Oyekunle', \\ Olugbenga S. Taiwo ${ }^{2}$, Alaba O. Adeyemi ${ }^{3}$
}

1 Chemical Engineering Department, Covenant University, P.M.B 1023, Canaan Land, Sango, Ogun State, Nigeria

2 Department of Biological Sciences, Covenant University, P.M.B 1023, Canaan Land, Sango, Ogun State, Nigeria

3 Department of Biochemistry, Covenant University, P.M.B 1023, Canaan Land, Sango, Ogun State, Nigeria

* Corresponding author's e-mail: modupe.ojewumi@covenantuniversity.edu.ng

\begin{abstract}
The aim of this project work was to evaluate the effect of bacteria - Serratia in the enzymatic hydrolysis of Foolscap [FS] and Newspaper [NP] into fermentable or reducing sugars. The effect of temperature and hydrolysis time (number of days) on the extent of concentration of reducing sugar yield were assessed and quantified using Dinitrosalicylic acid test method (DNS). A proximate analysis was carried out on the substrate before hydrolysis. Alkaline pre-treatment using sodium hydroxide and deinking process for the removal of paper with ink for higher susceptibility of the substrate before the enzymatic hydrolysis were carried out. The temperature effect on the waste sample were analysed at $37^{\circ} \mathrm{C}, 40^{\circ} \mathrm{C}$ and $45^{\circ} \mathrm{C}$ for 7 days, it was observed that at $37^{\circ} \mathrm{C}$, saccharification was higher than at $40^{\circ} \mathrm{C}$ and $45^{\circ} \mathrm{C}$. The general observation was in that Serratia had a very good effect on the waste paper samples. A 3-D surface plot revealed that the yield of sugar increased along with the hydrolysis time (number of days), with Foolscap having the highest yield of about $21 \mathrm{mg} / \mathrm{ml}$. The comparative analysis shows that the highest yield was obtained at the temperature of $37^{\circ} \mathrm{C}$, for both substrates used.
\end{abstract}

Keywords: Serratia, waste paper, enzymatic hydrolysis, fermentable sugars, microorganisms

\section{INTRODUCTION}

Waste materials such as paper, agricultural biomass and cooking oil can be very useful when properly recycled [1-4]. However, paper products are presently recycled on a limited basis Most waste papers are usually dumped or burnt, thus increasing the rate of environmental pollution [5]. Therefore, the use of enzymes as a catalyst in the bioconversion of waste paper materials to fermentable sugars is an important step that needs to be considered in the producing sugars using an environmental-friendly process [6]. Crude oil constitutes another material that pollutes environment. This can be remediated using microorganisms [7-10].

Cellulose is a naturally abundant material that can be derived from the sources that are sustainable and renewable, biodegradable, carbon neutral and are environmentally safe [11]. It can be obtained from bacteria [12], cotton [13], sisal [14], tunicates [15], wood pulps [16] and ramine [17]. Cellulose, lignin and hemicellulose are essential components of lignocellulosic biomass which include different parts of plants that serve as paper materials, such as woods and leaves [18]. Hemicellulose, a primary component of xylose is responsible for the interlink bonds present in cellulose molecules [19]. Paper and material structural strength is due to the presence of lignin, possessing a high degree of different interconnected molecular structure. Shleser [20] reports that newspaper contains nearly $61 \%$ of cellulose and $16 \%$ hemicellulose; therefore, these materials can serve as an appropriate feed stock for the production of sugars.

Recycling of waste paper has led to reduction in the cellulose fiber length, having lower quality 
compared to the paper originally manufactured from pulps [21]. It is therefore advised that waste paper should be promoted as bioenergy resource due to the high expense required in recycling papers and the high cellulosic content of the recycled papers.

Waste paper would contribute greatly to solid waste if they are not recycled. When this waste is not properly managed it can turn into a serious environmental problem. An alternative means by which solid wastes are treated include incineration [22], land filling [23], waste organic materials are exposed to biochemical and chemical methods in other to aid the release of fermentable sugars, this occurs while the cellulose component of waste materials is broken down. The chemical procedure involves the use of inorganic acids such as sulphuric [24] and hydrochloric acids [25] in hydrolysing the cellulolytic content. This is an expensive method and it is not environmentally friendly, the resulting acid solution is difficult to recycle for further use on other cellulolytic waste materials available [26]. Other methods of degrading the waste cellulose material is the use of cellulase which is a multi-component enzyme system [21].

\section{MATERIALS AND METHODS}

The paper materials used for this investigation were foolscap papers and newspaper. These materials were obtained from the Covenant University environs. Microorganism Serratia was sourced from Applied Biology and Biotechnology Unit Laboratory of Covenant University, Ota, Ogun State.

Preparation of cellulase done using the method [6, 27-30]. Deinking and Alkaline Pre-treatment were carried out using the method [6].

The method of [31-33] was used to analyse the percentage of moisture, ash, crude fibre composition, the carbohydrate content was determined using the Anthrone method.

The waste papers with the sizes $2 \mathrm{~cm}$ by $2 \mathrm{~cm}$ were physically sorted and treated. $5 \mathrm{~g}$ of each paper substrate were soaked in $100 \mathrm{ml}$ of $2.0 \mathrm{M}$ $\mathrm{NaOH}(1 \%)$ solution in a flask and kept for the duration of 24 hours. Deinking was carried out on papers with ink. The paper substrate were soaked in $4 \%$ sodium hypochlorite for $48 \mathrm{~h}$, and then washed with water until neutralized ( $\mathrm{pH}$ of 7) and left to dry overnight at $105^{\circ} \mathrm{C}$ in the oven.

Enzymes, as generally known, are specific in action and are active in operation under specific conditions, which are popularly known as optimum conditions. General optimum conditions for such type of bacteria are within the range of $35^{\circ}$ to $50^{\circ} \mathrm{C}$; hence, the analysis was focused within the range. For this work, $37^{\circ} \mathrm{C}, 40^{\circ} \mathrm{C}$ and $45^{\circ} \mathrm{C}$ were used. The pre-treated paper substrates were mixed with $1 \mathrm{ml}$ Serratia solution and incubated for 1 week at a temperature range of $37^{\circ} \mathrm{C}$ to $45^{\circ} \mathrm{C}$. The samples were withdrawn daily and analysed using the DNS acid method for reducing sugars.

Test for Reducing Sugar. The test for reducing sugar was carried out using the DNS acid test. The absorbance was recorded for each sample that was collected.

The standard glucose solution was prepared by the dissolution of $100 \mathrm{mg}$ of glucose in 100 $\mathrm{ml}$ of distilled water. The working standard solution was prepared by pipetting out $10 \mathrm{ml}$ of stock standard solution into a flask and diluting it to 100 $\mathrm{ml}$ with distilled water.

0 to $1.0 \mathrm{ml}$ of the working standard solution were collected in separate test tubes. The volume of each test tube was made up to $3 \mathrm{ml}$ using distilled water. $1.0 \mathrm{ml}$ of distilled water was used as blank. The absorbance of each sample was read following the DNS method below.

$1 \% \mathrm{NaOH}$ was prepared by dissolving $1 \mathrm{~g}$ of $\mathrm{NaOH}$ in $100 \mathrm{ml}$ of distilled water, $1 \mathrm{~g}$ of Dinitrosalicylic acid, $200 \mathrm{mg}$ crystalline phenol and 50 $\mathrm{mg}$ of sodium sulphite were dissolved in $100 \mathrm{ml}$ of $1 \% \mathrm{NaOH}$. $40 \%$ of potassium sodium tartrate was prepared by dissolving $40 \mathrm{~g}$ of potassium sodium tartrate in $100 \mathrm{ml}$ of distilled water.

The supernatant of the entire sample was collected using a pipette. $1 \mathrm{ml}$ of each supernatant was collected and the volume was equalized to $3 \mathrm{ml}$ using distilled water. $1 \mathrm{ml}$ of Dinitrosalicylic acid solution was added to each test tube containing the samples. The contents of the test tubes were boiled in a water bath for 10 minutes. $1 \mathrm{ml}$ of $40 \%$ potassium sodium tartrate was added to each test tube while they were warm. The tubes were allowed to cool and the absorbance was read at $575 \mathrm{~nm}$.

\section{RESULTS AND DISCUSSION}

Table 1 shows the proximate analyses carried out on the two samples of paper used. It was revealed that Newspaper had the highest composition in three (3) out of four (4) tests carried out under the proximate analysis on the raw substrate. 
The higher moisture content might probably be due to where the papers were picked from - Library where air conditioning operates for about 14 hours daily. The crude ash content was found to be higher in the foolscap sample with $9.76 \%$; the crude ash content indicates the presence of mineral. The carbohydrate content of the paper samples using the Anthrone method was recorded with Newspaper having the highest concentration of carbohydrate of $40.03 \mathrm{mg} / \mathrm{ml}$. The result obtained proved that the proximate values have no effect on the yield of fermentable sugar produced, since Foolscap produced more.

Figures 1-3 show the yield of reducing sugar in both waste paper samples hydrolysed for one week (7 days). It was observed that foolscap had the highest concentration of sugar, followed by Newspaper irrespective of the total carbohydrate composition present in the substrate used. The reducing sugar yield is dependent on days of hydrolysis. The more the days, the greater sugar yield obtained.

Figures 4 and 5 show the effects of different temperature on the yield of the reducing sugar (comparative analysis). After 7 days (1 week) of enzymatic hydrolysis at a temperature of $37^{\circ} \mathrm{C}$, the concentration of reducing sugar was measured daily to observe the trend of increase or decrease and the results were recorded. The general trend of the concentration of the fermentable sugar was on the increase from the first day to the seventh day for both FS and NP, this is a similar observation to the work carried out by [34] on the biodegradation of five paper samples using Trichoderma viride as cellulase. The results indicated that the effect of Serratia on the waste paper samples after a week at $37^{\circ} \mathrm{C}$, had the highest effect on the
Table 1. Proximate analyses on waste paper samples

\begin{tabular}{|c|c|}
\hline Specifications & Value \\
\hline $\mathrm{pH}( \pm 0.01)$ & 7.99 \\
\hline $\mathrm{EC}(\mu \mathrm{S} / \mathrm{cm})( \pm 1)^{1}$ & 52200 \\
\hline $\operatorname{TDS}(\mathrm{mg} / \mathrm{L})( \pm 0.1)^{2}$ & 36540.0 \\
\hline T. Hardness $\left(\mathrm{mgCaCO}_{3} / \mathrm{L}\right)( \pm 0.01)^{3}$ & 6142.00 \\
\hline C. Hardness $\left(\mathrm{mg} \mathrm{CaCO}_{3} / \mathrm{L}\right)( \pm 0.01)^{4}$ & 1018.50 \\
\hline M. Hardness $\left(\mathrm{mgCaCO}_{3} / \mathrm{L}\right)( \pm 0.01)^{5}$ & 5123.50 \\
\hline T. Alkalinity $\left(\mathrm{mgCaCO}_{3} / \mathrm{L}\right)( \pm 0.01)^{6}$ & 263.30 \\
\hline $\mathrm{HCO}_{3}-$ Alkalinity $\left(\mathrm{mgCaCO}_{3} / \mathrm{L}\right)( \pm 0.01)$ & 263.30 \\
\hline Turbidity (NTU) $( \pm 0.01)$ & 0.20 \\
\hline L. Index $( \pm 0.01)^{7}$ & 1.31 \\
\hline $\mathrm{Ca}^{+2}(\mathrm{mg} / \mathrm{L})( \pm 0.01)$ & 407.40 \\
\hline $\mathrm{Mg}^{+2}(\mathrm{mg} / \mathrm{L})( \pm 0.01)$ & 1228.66 \\
\hline $\mathrm{Na}^{+} \quad(\mathrm{mg} / \mathrm{L})( \pm 0.1)$ & 7800.0 \\
\hline $\mathrm{K}^{+}(\mathrm{mg} / \mathrm{L})( \pm 0.01)$ & 437.5 \\
\hline Silica $(\mathrm{mg} / \mathrm{L})( \pm 0.01)$ & 0.00 \\
\hline $\mathrm{Cl}^{-}(\mathrm{mg} / \mathrm{L})( \pm 0.01)$ & 14704.92 \\
\hline $\mathrm{SO}_{3}^{-2}(\mathrm{mg} / \mathrm{L})( \pm 0.1)$ & 2618.8 \\
\hline $\mathrm{NO}_{3}(\mathrm{mg} / \mathrm{L})( \pm 0.01)$ & 0.00 \\
\hline $\mathrm{F}^{-}(\mathrm{mg} / \mathrm{L})( \pm 0.001)$ & 2.79 \\
\hline $\mathrm{PO}_{4}^{-3}(\mathrm{mg} / \mathrm{L})( \pm 0.001)$ & 0.001 \\
\hline
\end{tabular}

foolscap substrate samples which could be due to the high susceptibility to yield high concentration of sugar.

Reducing sugar was also produced at $40^{\circ} \mathrm{C}$ but not as much as at $37^{\circ} \mathrm{C}$; however, lesser yield was recorded for the highest temperature, i.e. $47^{\circ} \mathrm{C}$. Thus, we can deduce that Serratia operates best at the temperature between $37^{\circ}$ and $40^{\circ} \mathrm{C}$, since higher yield was recorded at these two temperatures. Although bacterial enzymes such Serratia used for this work have an optimum range of temperature that aid its microbial activities $\left(37-45^{\circ} \mathrm{C}\right)$, this is seen from the work

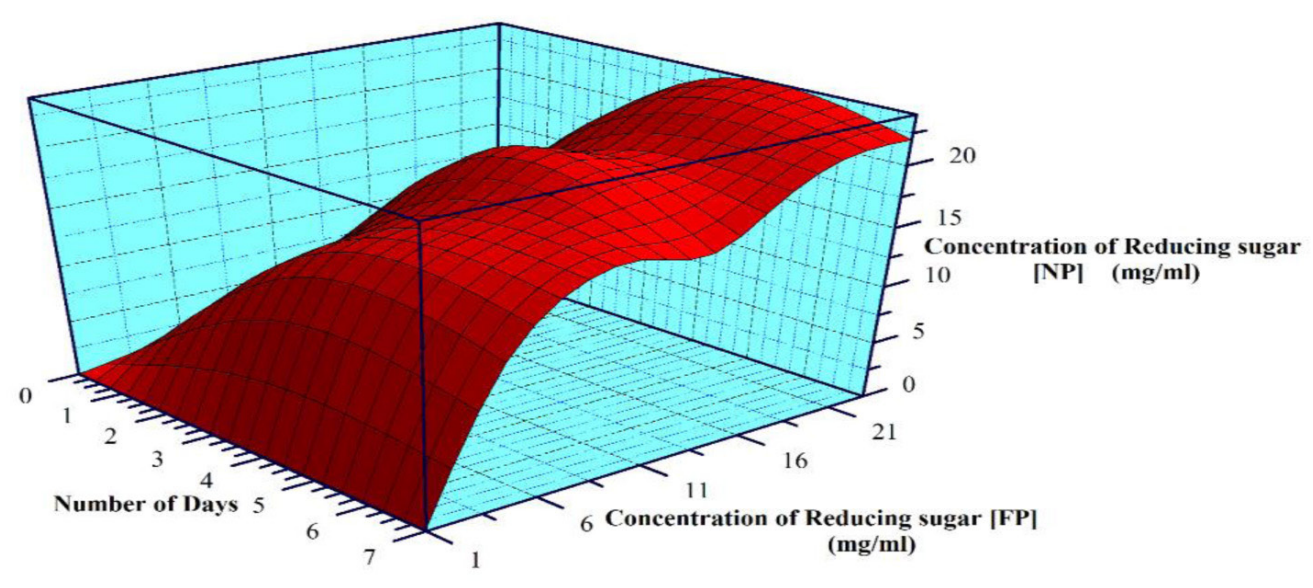

Figure 1. Effect of hydrolysis time (number of days) on the concentration of reducing sugar obtained from Foolscap [FP] and Newspaper [NP] using Serratia at temperature $37^{\circ} \mathrm{C}$ 


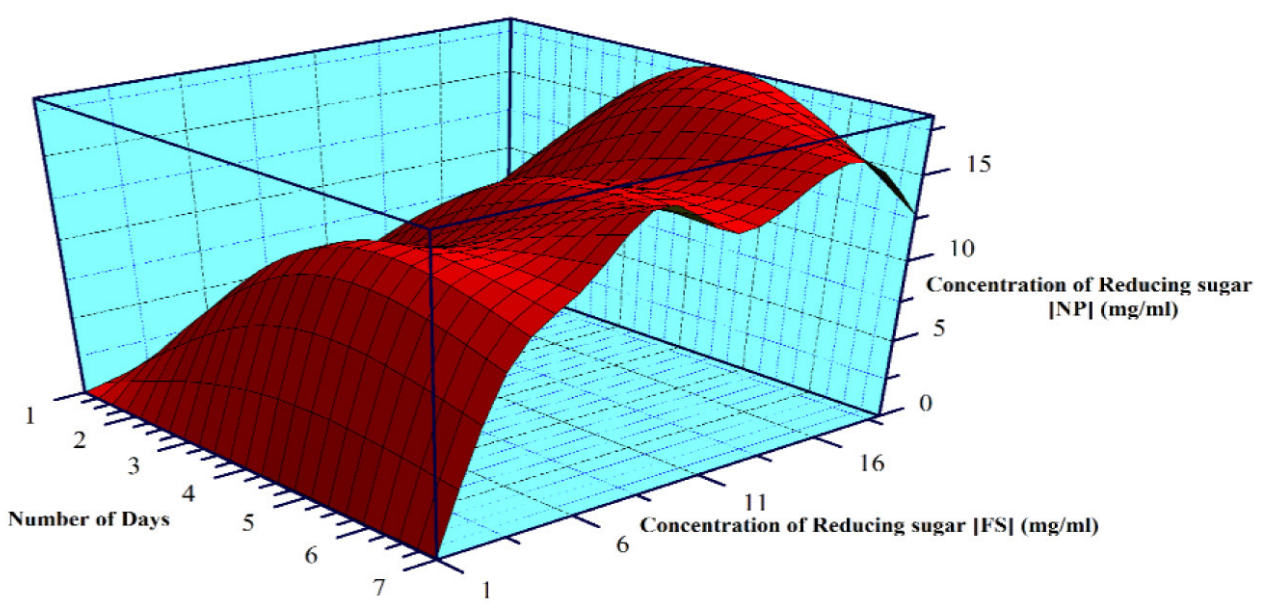

Figure 2. Effect of hydrolysis time (number of days) on the concentration of reducing sugar obtained from Foolscap [FP] and Newspaper [NP] using Serratia at $40^{\circ} \mathrm{C}$

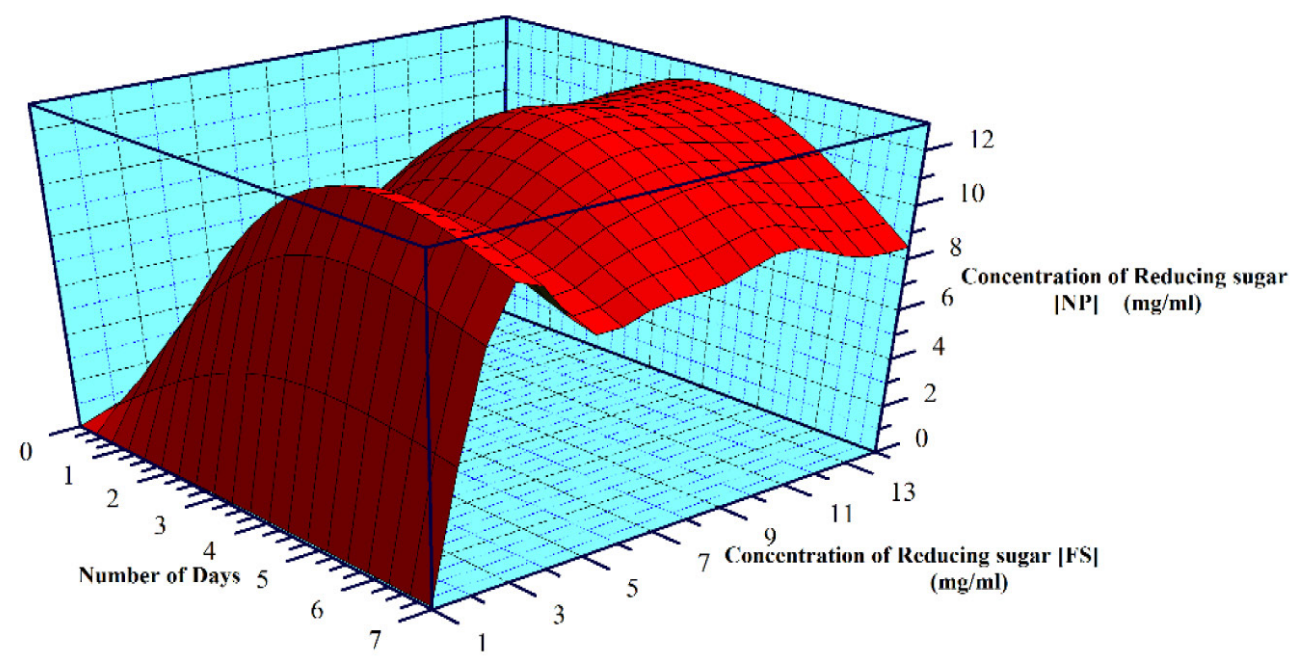

Figure 3. Effect of hydrolysis time (number of days) on the concentration of reducing sugar obtained from Foolscap [FP] and Newspaper [NP] using Serratia at $45^{\circ} \mathrm{C}$

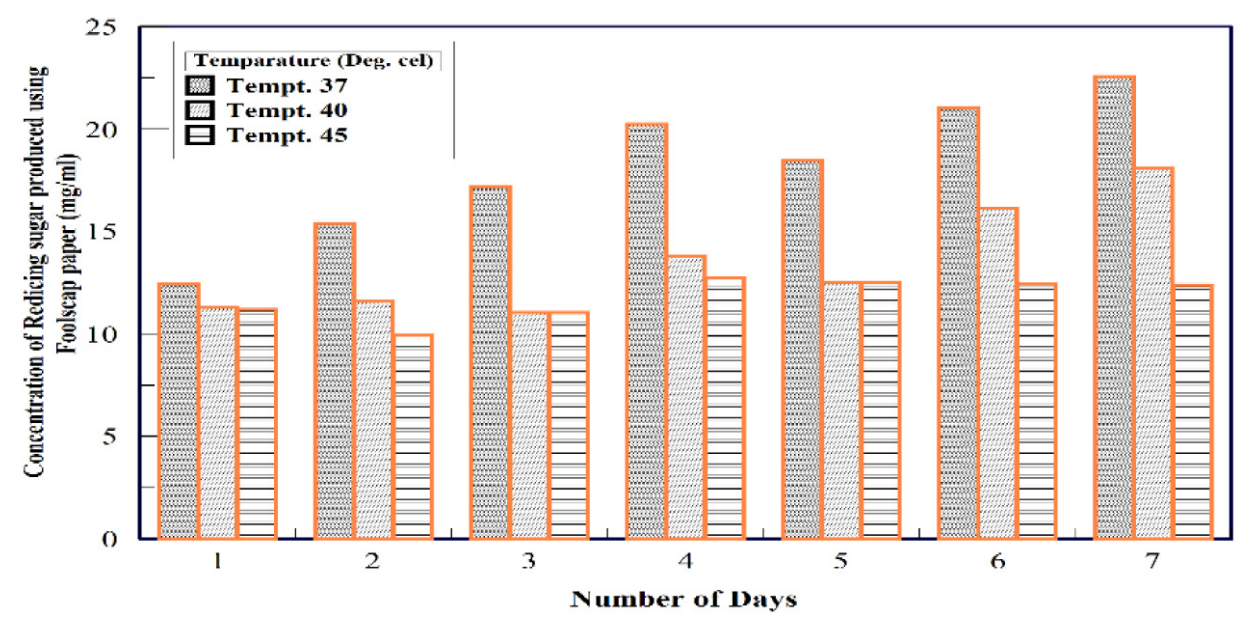

Figure 4. Effect of different temperature on the yeild of Reducing sugar using Foolscap paper as substrate 


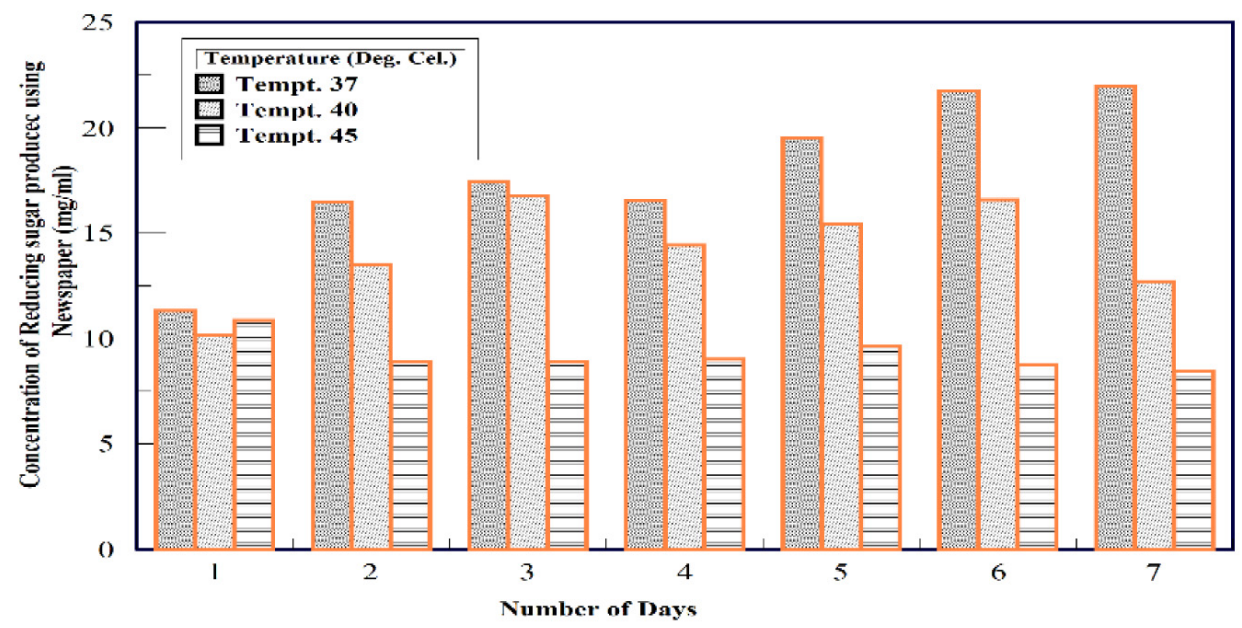

Figure 5. Effect of different temperature on the yeild of Reducing sugar using Newspaper as substrate

of [35] on the effect of high growth temperature on Serratia marcescens; therefore, the trend being studied is not a situation of a temperature increase above the optimum, but rather that $37^{\circ} \mathrm{C}$ is a more suitable temperature for high saccharification than $40^{\circ} \mathrm{C}$ and $45^{\circ} \mathrm{C}$.

However, the comparative analysis of the temperature and the metabolites shows that the $37^{\circ} \mathrm{C}$ is a more optimum temperature in the production of reducing sugar from the waste paper substrates and also that Serratia have the highest effects in the bioconversion on the paper samples used.

\section{CONCLUSION}

Serratia have the ability to degrade papers into fermentable sugars. The temperature range of $37^{\circ} \mathrm{C}$ to $45^{\circ} \mathrm{C}$ is an optimum temperature range for the bacterial actions on the substrate (waste paper samples); also, the temperature $37^{\circ} \mathrm{C}$ is a better temperature for saccharification than $40^{\circ} \mathrm{C}$ and $45^{\circ} \mathrm{C}$. The enzymatic hydrolysis of waste paper is of major interest, seeing it could be an alternative solution for the solid waste material treatment and corresponding glucose and more so, ethanol production. The waste papers that cannot be recycled can be utilized in the production of glucose syrups of very high purity level in glucose for industrial and commercial satisfaction. The bioconversion process is "environmentally friendly" because no harmful side products are obtained at any time during the process, also the demand for energy during the process is low.

\section{Acknowledgements}

The authors appreciate the sponsorship of Covenant University.

\section{REFERENCES}

1. Ojewumi M.E., Emetere M.E., Amaefule C.V., Durodola B., Adeniyi O.D., 2019. Bioconversion of orange peel waste by escherichia coli and saccharomyces cerevisiae to ethanol. International Journal of Pharmaceutical Sciences and Research, 10(3), 1000-07.

2. Ojewumi M.E., Ayomide A.A., Obanla O.M., Ojewumi E.O., 2014. Pozzolanic properties of Waste Agricultural Biomass-African Locust Bean Pod Waste. World Journal of Environmental Biosciences, 6(3), 1-7.

3. Ojewumi M.E., Akwayo I.J., Taiwo O.S., Obanla O.M., Ayoola A.A., Ojewumi E.O. Oyeniyi E.A, 2018. Bio-Conversion of Sweet Potato Peel Waste to BioEthanol Using Saccharomyces Cerevisiae, International Journal of Pharmaceutical and Phytopharmacological Research, 8(3), 46-54.

4. Owolabi R., Osiyemi N., Amosa M., Ojewumi M.E., 2011. Biodiesel from household/restaurant waste cooking oil (WCO). J Chem Eng Process Technol, 2(112), p. 700,000-1,000,000.

5. Varotkar P., Tumane, P.M., Wasnik, D.D., 2016. Bioconversion of Waste Paper into Bio-Ethanol by Co-Culture of Fungi Isolated from Lignocellulosic Waste. International Journal of Pure and Applied Bioscience, 4(4),. 264-274,

6. Ojewumi M.E., Obielue B.I., Emetere M.E., Awolu O.O., Ojewumi E.O., 2018. Alkaline Pre-Treatment and Enzymatic Hydrolysis of Waste Papers to Fermentable Sugar. Journal of Ecological Engineering, 19(1), 211-217. 
7. Ojewumi M.E., Emetere M.E., D.E. Babatunde, Okeniyi O.J., 2017. In-situ bioremediation of crude petroleum oil polluted soil using mathematical experimentation, International Journal of Chemical Engineering, Vol. 2017, Article ID 5184760, 11 pages, https://doi.org/10.1155/2017/5184760.

8. Ojewumi M.E., Ejemen V.A., Taiwo O.S., Adekeye B.T., Awolu O.O., Ojewumi E.O., 2018. A Bioremediation Study of Raw and Treated Crude Petroleum Oil Polluted Soil with Aspergillus niger and Pseudomonas aeruginosa. Journal of Ecological Engineering, 19(2), 226-235, https://doi. org/10.12911/22998993/83564.

9. Ojewumi M.E., Okeniyi J.O., Ikotun J.O., Okeniyi E.T., Ejemen V.A., Popoola A.P.I., 2018. Bioremediation: Data on Pseudomonas aeruginosa effects on the bioremediation of crude oil polluted soil. Data in Brief, 19, 101-113,

10. Ojewumi M.E., Okeniyi J.O., Okeniyi E.T., Ikotun J.O., Ejemen V.A., Akinlabi E.T., 2018. Bioremediation: Data on Biologically-Mediated Remediation of Crude Oil (Escravos Light) Polluted Soil using Aspergillus niger. Chemical Data Collections, 17-18, 196-204

11. Klem D., Heublein, B., Fink, H., Bahn, A., 2005. Cellulose: Fascinating Biopolymer and Sustainable Raw Material. Angewandte Chemie International Edition, 44(22), 3358-3393.

12. Roman M., Winter, W.T., 2004. Effect of sulfate groups from sulfuric acid hydrolysis on the thermal behavior of bacterial cellulose. Biomacromolecules, 5(5), 1671-1677.

13. Uddin A.J., Araki, J., Gotoh, Y., 2011. Characterization of the poly (vinylalcohol) cellulose whiskers gel spun fibers. Composites A. Applied Science and Manufacturing, 42(7), 741-747.

14. Garcia De Rodriguez N.L., Thielemans, W., 2006. Dufresne, A., Sisal cellulose whiskers reinforced polyvinyl acetate nanocomposites. Cellulose, 13(3), 261-270.

15. Angles M.N., Dufresne, A., 2009. Plasticized starch/ tunicin whiskers nanocomposites, I, Structural analysis. Macromolecules, 33(22), 8344-8353.

16. Dong H., Strawhecker, K.E., Snyder, J.F, Orlicki, T.A., Reiner, R.S., Rudie, A.W., 2012. Cellulose nanocrystals as a reinforcing material forelectrospun poly (methyl methacrylate) fibers: formation, properties and nanomechanical characterization carbohydrate. Carbohydrate Polymers, 87, 2488-2495.

17. Peresin M.S., Habibi, Y., Zoppe, I.O., Pawlak, J. J., Rojas, O. J., 2010. Nanofiber composites of polyvinyl alcohol and cellulose nanocrystals: Manufacture and characterization. Biomacromolecules, 11(3), 674-681.

18. Van Wyk J.P.H., Mogale, M.A., Moroka, K.S., 1999. Bioconversion of waste paper materials to sugars: An application illustrating the environmental benefit of enzymes. Biochemical Education, 27(4), 227-228.

19. Ladish M.R.L., Voloch K.W., Tsao M., 1983. Process considerations in the enzymatic hydrolysis of biomass. Enzyme and Microbial Technol., 5(2), 82-102.

20. Shleser R., 1994. Ethanol production in Hawaii: Processes, feedstock, and current economic feasibility of fuel grade ethanol production in Hawaii. Final Report. State of Hawaii, USA: Department of Business,Economic Development and Tourism. p. 1-87.

21. Sibiya J.B.M., Wyk, J. P., 2016. Bioconversion of waste newspaper into fermentable sugars at different temperatures with different Aspergillus niger cellulase concentrations. Journal of Applied Biology \& Biotechnology, 4(04), 69-74.

22. Li Y., Zhao, X., Li, Y., Li, X., 2015. Waste incineration industry and development policies in China. Waste Management, 46, 234-241.

23.Zang Y., Yue, D., Nie, Y., 2012. Greenhouse gas emissions from two stage land filling of municipal solid waste. Atmospheric Environment, 55, 139-143.

24. Girisuta B., Janssen, L.P.B.M., Heeres, H.J., 2007. Kinetic study on the acid - catalyzed hydrolysis of cellulose to Levulinic acid. Industrial Engineering and Chemical Research, 46(6), 1696-1708.

25. Sun Y., Yang, G., Jia, Z., Wen, C., Zhang, L., 2014. ACTA hydrolysis of corn stover using hydrochloric acid: Kinetic modelling and statistical optimization. Chemical Industry and Chemical Engineering Quarterly, 20(4), 531-539.

26. Bensah E.C., Mewsah, M., 2013. Chemical pretreatment methods for ethanol: Technologies and innovation. International Journal of Chemical Engineering, 20(13), 21-40.

27. Ojewumi M.E., Omoleye J.A., Ajayi A.A., 2016. Optimum fermentation temperature for the protein yield of parkia biglobosa seeds (Iyere). 3rd International Conference on African Development Issues, Covenant University, Ota, Ogun State (CUICADI 2016).

28. Ojewumi M.E., Omoleye J.A., Ayoola A.A., Ajayi A.A., Adekeye B.T., Adeyemi A.O., 2018. Effects of Salting and Drying on the Deterioration Rate of Fermented Parkia biglobosa Seed. Journal of Nutritional Health \& Food Engineering, 8(1), 1-5.

29. Ojewumi M.E., Omoleye J.A., Ajayi A.A., 2016. The Effect of Different Starter Cultures on the Protein Content in Fermented African Locust Bean (Parkia Biglobosa) Seeds. International Journal of Engineering Research \& Technology (IJERT), 5(4), 249-255. 
30. Ojewumi M.E., Omoleye J.A., Emetere M.E., Ayoola A.A., Obanla O.M., Babatunde D.E., Ogunbiyi A.T., Awolu O.O., Ojewumi E.O., 2018. Effect of various temperatures on the nutritional compositions of fermented African locust bean (Parkia biglobosa) seed. International Journal of Food Science and Nutrition, 3(1), 117-122.

31. Ojewumi M.E., Omoleye J.A., Ajayi A.A., 2016. The Study of the Effect of Moisture Content on the Biochemical Deterioration of Stored Fermented Parkia Biglobosa Seeds. Open Journal of Engineering Research and Technology, 1(1), 14-22.

32. Ojewumi M.E., Oyeyemi K.G., Emetere M.E., Okeniyi J.O., 2018. Data on the rheological behav- ior of cassava starch paste using different models. Data in Brief, 19, 2163-2177.

33. Ojewumi M.E, Omoleye J.A. Ajayi A.A., 2017. Optimization of Fermentation Conditions for the Production of Protein Composition in Parkia biglobosa Seeds using Response Surface Methodology. International Journal of Applied Engineering Research, 12(22), 12852-12859.

34. Van Wyk J., Mohulatsi M., 2003. Biodegradation of wastepaper by cellulase from Trichoderma viride. Bioresource Technology, 86(1), 21-23.

35. Stancu M.M., 2017. Effect of high growth temperature on Serratia marcescens. Romanian Biotechnological Letters. 